Горб К. О., здобувач вищої освіти ступеня доктора філософії

Полтавська державна аграрна академія

\title{
ЕПІЗООТОЛОГІЧНІ ОСОБЛИВОСТІ КТЕНОЦЕФАЛЬОЗУ СОБАК В УМОВАХ МІСТА ПОЛТАВИ
}

\section{Рецензент - кандидат ветеринарних наук О. В. Кручиненко}

\begin{abstract}
Мета статmі - дослідження епізоотологічних особливостей ктеноцефальозу собак на території міста Полтава, оскільки ктеноцефальоз є одним із найбільш розповсюджених захворювань собак, щзо виникає внаслідок зараження блохами роду Ctenocephalides.

Методика дослідження. Методологічною основою дослідження слугували такі наукові методи: аналіз і синтез (встановлення показників інвазованості собак блохами; визначення вікової динаміки ктеноцефальозу собак), теоретичний пошук і абстрактно-логічний (аналіз досліджень щодо захворювання собак ктеночефальозом, що викликається блохами роду Ctenocephalides), графічний (відображення результатів досліджень графічно).
\end{abstract}

Результати дослідження. У статті наведено результати досліджень щодо вивчення потирення ктеноцефальозу собак на території міста Полтави, зважаючи на залежність показників екстенсивності інвазії від породи та віку тварин. Ентомологічні дослідження проводили методом вичісування волосяного покриву собак та збору бліх з типових місиь їх проживання на тілі тварини. Ктеноиефальоз виявлений нами у собак старших одного року. Однак максимально заражаються блохами собаки віком від одного до шести років (EI - 50,0-62,8\%). 3'ясовано, щзо найбільш сприйнятливими до збудників ктеноцефальозу виявилися собаки мисливських порід (EI - 53,5\%) та безпородні тварини (EI-60,7\%). Найменш ураженими були собаки декоративних порід (EI-18,6\%).

Елементи наукової новизни. Доведено, що ктеноцефальоз є поширеною інвазією собак на території міста Полтави. Причому до інвазування блохами виявилися схильними тварини обох статей. Визначено показники інвазованості собак блохами; виявлено вікову динаміку ктеноцефальозу собак; досліджено породну сприйнятливість собак до збудників ктеноцефальозу.

Практична значущість. Вивчення епізоотичної ситуаиї щодо ктеноцефальозу собак в умовах м. Полтави здійснювалося за результатами досліджень тварин, які поступали у ветеринарний сервіс «Vetexpert» з різних адміністративних районів м. Полтави упродовж 2017-2018 рр. Усього обстежено 187 собак. Середня екстенсивність інвазії становила 43,85\%. Встановлено, що найбільш сприйнятливими до кровосисних комах серед собак декоративних порід є китайська чіхуа-хуа (50,0\%), мисливських порід - лабрадор-ретривер та кокер-спанієль (60,0-63,6\%), службових порід німецька вівчарка та американський стафордширський тер'єр (62,9-71,4\%).

Ключові слова: ктеноцефальоз, собаки, поширення, вікова диналіка, породна сприйнятливість.

Горб Ксенія Олегівна - здобувач вищої освіти ступеня доктора філософії кафедри паразитології та ветеринарно-санітарної експертизи, Полтавська державна аграрна академія, вул. Сковороди, 1/3, м. Полтава, 36003, Україна, e-mail: ksenia_92@ukr.net.

Постановка проблеми. У сучасних умовах домашні м'ясоїдні є «компаньйонами» людини в побуті та в багатьох сферах іiі діяльності. Собака не просто «друг» людини, але і «соратник» у мирному житті, і неоціненний помічник в екстремальних умовах. У багатьох випадках домашні м'ясоїдні тварини $є$ членами сім'ї сучасного мешканця міста, а тому стан їх здоров'я $є$ постійною турботою людини. Серед хвороб, які реєструються у домашніх м'ясоїдних, зокрема собак, спостерігаються й такі недуги, що властиві не тільки цим тваринам, їх можна виявити в інших видів тварин і навіть у людини $[1,2,11]$.
Найбільше у собак реєструються ентомози, викликані ектопаразитами, що живляться кров'ю. Найбільш відомими і поширеними ектопаразитами домашніх м'ясоїдних тварин $є$ блохи, які, крім того, є переносниками збудників багатьох інфекційних та інвазійних хвороб $[3,5]$.

Аналіз останніх досліджень і публікацій, у яких започатковано розв'язання цісї проблеми. Науковцями доведено, що одним із найбільш розповсюджених захворювань собак $\epsilon$ ктеноцефальоз, що виникає внаслідок зараження блохами роду Ctenocephalides. Більшість видів бліх паразитує на тваринах певного виду або 


\section{ВЕТЕРИНАРНА МЕДИЦИНА}

групи видів, але досить легко можуть змінювати своїх хазяїв. Нечасто серед них реєструються специфічні паразити, прив'язані тільки до одного або кількох близьких видів тварин, які навіть після тривалого голодування не можуть пити кров незвичайного для них хазяїна. Для багатьох інших видів бліх кров чужих для них тварин $\epsilon$ неповноцінною їжею, вони припиняють розмножуватися, а термін їхнього життя скорочується [8, 9].

Ктеноцефальоз виявлено у м'ясоїдних тварин в Аргентині, Австралії, Данії, Сгипті, Німеччині, Великобританії, США, де показники екстенсивності інвазії коливалися в межах від 1,4 до $100 \%$ [10].

За даними науковців, на території мегаполісу Москви зараженість собак Ctenocephalides felis приблизно становить 26,64\%. Причому найбільш інвазованими виявилися безпритульні собаки, екстенсивність інвазії сягає $100 \%$. Також дослідниками доведено, що 3 віком зараженість собак блохами значно зменшується і максимальні показники екстенсивності інвазії (до 44,4%) виявлені у тварин віком від 7 міс. до 2 років. Одержані результати вивчення впливу породи собак на їх зараженість ектопаразитами свідчать про меншу інвазованість собак ектопаразитами декоративних та мисливських порід (EI - 10 та $8,6 \%$ ). Водночас найбільш зараженими виявилися собаки службових порід (EI - 46 \%) та безпородні тварини (36,8 \%) у зв'язку з несвоєчасним проведенням або відсутністю регулярних профілактичних інсектицидних обробок [4].

Більшість дослідників указують на зростання захворюваності домашніх м'ясоїдних тварин ентомозами, що спричиняють блохи, пояснюючи це збільшенням чисельності популяції домашніх i безпритульних собак, які створюють напружену епізоотологічну ситуацію щодо інвазійних хвороб у містах та селах, оскільки сприяють зростанню чисельності паразитів [6, 7].

Отже, метою роботи є вивчення епізоотологічних особливостей ктеноцефальозу собак на території міста Полтави. Серед завдань дослідження: встановити показники інвазованості собак блохами; визначити вікову динаміку ктеноцефальозу собак; дослідити породну сприйнятливість собак до збудників ктеноцефальозу.

Матеріали і методи досліджень. Дослідження проводилися упродовж 2017-2018 рр. на базі лабораторії кафедри паразитології та ветеринар- но-санітарної експертизи Полтавської державної аграрної академії.

Вивчення епізоотичної ситуації щодо ктеноцефальозу собак в умовах м. Полтави здійснювали за результатами досліджень тварин, які поступали у ветеринарний сервіс «Vetexpert» 3 різних адміністративних районів м. Полтави.

У процесі епізоотичного обстеження тварин основним показником ураження собак блохами була екстенсивність інвазії (ЕI). Ентомологічні дослідження проводили методом вичісування волосяного покриву собак та збору бліх 3 типових місць їх проживання на тілі тварин.

Вікову та породну динаміки ктеноцефальозу собак досліджували на тваринах двадцяти двох різних порід (серед них: 9 - декоративних, 7 службових, 5 - мисливських), метисах і безпородних собаках п'яти вікових груп: до 1 року, 13 роки, 3-6 років, 6-10 років та старші 10-ти років. Усього обстежено 187 собак.

Результати досліджень. За результатами дослідження встановлено, що ктеноцефальоз є поширеною інвазією собак на території міста Полтави. Середня екстенсивність інвазії становить 43,85 \%. Причому до інвазування блохами виявилися схильними тварини обох статей. Аналізуючи одержані дані клінічного огляду 82-х заражених блохами собак (з них 42 суки і 40 кобелів), не встановлено суттєвої різниці в показниках зараженості кровосисними комахами. Зараженість сук становила 51,2 \%, кобелів - 48,8 \%.

Ктеноцефальоз виявлений нами у собак старше однорічного віку, проте наявна різниця в зараженості блохами собак різного віку (рис. 1).

У собак віком до 1 року бліх клінічно на тваринах не виявлено. На нашу думку, це пов'язане 3 тим, що молоді тварини потребують більш ретельного догляду, тому господарі приділять належну увагу до проведення профілактичних інсектицидних обробок. Найбільше інвазованими блохами виявилися собаки віком від 1 до 3 р. $(\mathrm{EI}-50,0 \%)$ та від 3 до 6 p. (EI - 52,8 \%). Надалі, зважаючи на вік собак, показники екстенсивності інвазії зменшувалися і становили: у тварин 6-10 p. - 48,4\%, старші 10 р. - 19,2\%.

Зараженню блохами схильні всі собаки незалежно від породи (рис. 2). Причому найменше виявилися заражені собаки декоративних порід (EI - 18,6\%), що пояснюється їх квартирним утриманням. 


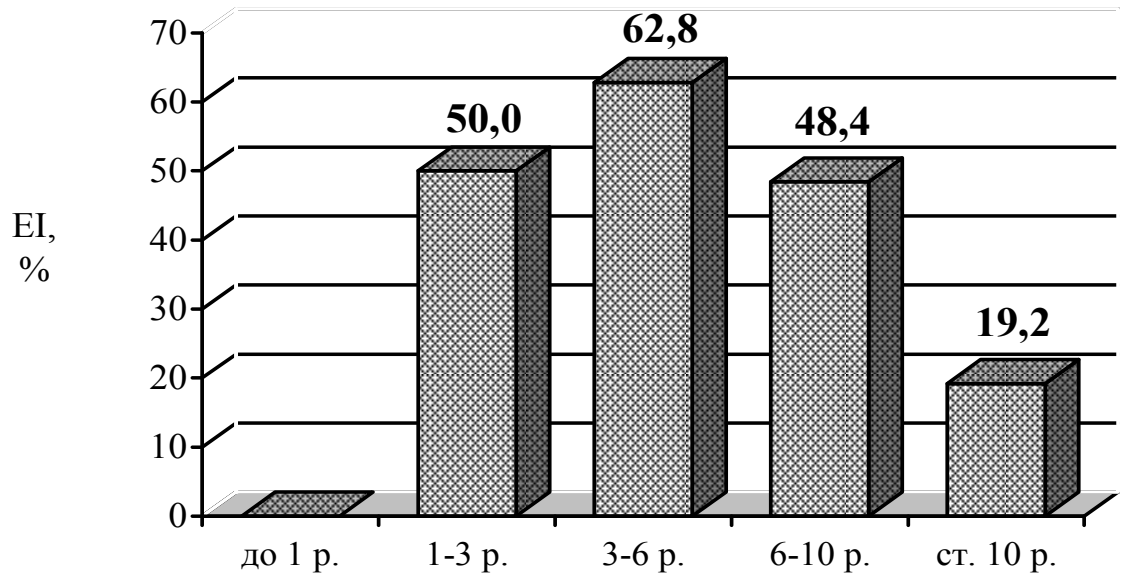

Вік собак

Рис. 1. Вікова динаміка ктеноцефальозу собак в умовах міста Полтави

Джерело: авторські дослідження.

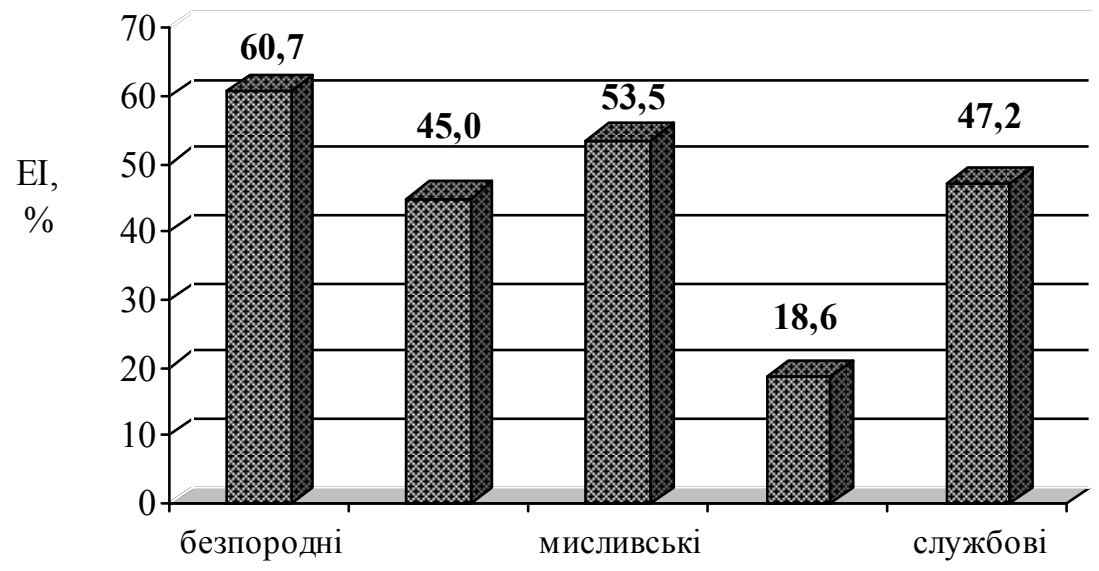

Рис. 2. Сприйнятливість собак різних порід та безпородних тварин до збудників ктеноцефальозу

Джерело: авторські дослідження.

Спостерігається високий відсоток зараженості собак мисливських порід (EI - 53,5\%) і безпородних тварин (ЕI - 60,7\%). Екстенсивність інвазії блохами метисів становила $45,0 \%$, собак службових порід - 47,2 \%. Доведено, що найбільш сприйнятливими до кровосисних комах серед собак декоративних порід $\epsilon$ китайська чіхуа-хуа $(50,0 \%)$, мисливських порід - лабрадор-ретривер та кокерспанієль (60,0-63,6 \%), службових порід - німецька вівчарка та американський стафордширський тер'єр (62,9-71,4\%).

Висновки. 1. В умовах міста Полтави встановлено значне поширення ктеноцефальозу собак, що спричинене блохами роду Ctenocephalides. Зараженість собак кровосисними комахами становить при- близно $43,85 \%$.

2. Визначено, що вікова динаміка за ктеноцефальозу характеризується максимальним ураженням собак віком від одного до шести років (EI - 50,0$62,8 \%)$.

3. Найбільш ураженими збудниками ктеноцефальозу виявилися безпородні собаки (EI - 60,7 \%) та собаки мисливських порід (53,5\%). Менш сприйнятливими виявилися собаки декоративних порід $(18,6 \%)$.

Перспективи подальшої роботи в цьому напрямі. Перспективами подальших досліджень $\epsilon$ визначення впливу бліх на гематологічні показники хворих собак. 


\section{БІБЛІОГРАФІЯ}

1. Ващченок В. С. Блохи - переносчики болезней человека и животных. Л. : Наука, 1988. 161 с.

2. Герасимчик В. A. Паразитозы сторожевых собак. Экология и животный мир. 2017. № 1. C. 8-14.

3. Головнина О. В. Арахноэнтомозы мелких домашних животных и методы борьбы с ними. Ветеринарная патология. 2007. №2(21). C. 195-197.

4. Лютикова И. А. Ктеноцефалидоз собак и кошек мегаполиса Москвы: распространение, патогенез, терапия: дис. канд. вет. наук: 03.00.19. Москва, 2008. 160 с.

5. Машкей И. А. Арахноентомози собак та кішок України. Проблеми ветеринарного обслуговування дрібних домамніх тварин. 1998. C. 14-16.

6. Медведев С.Г. Особенности распространения и паразито-хозяинных связей блох (Siphonaptera). Энтомологическое обозрение. 2002. Вып. 3, т. 81. С. 737-751.

7. Пономаренко А. М.,

Клімчук О. О.,

\section{REFERENCES}

1. Vashhenok, B. C. (1988). Blohi - perenoschiki boleznej cheloveka i zhivotnyh [Fleas - the Carriers of Human and Animal Diseases]. Leningrad: Nauka [In Russian].

2. Gerasimchik, V. A. (2017). Parazitozy storozhevyh sobak. Jekologija i zhivotnyj mir [Parasitoses of Watch Dogs]. Minsk: RUP «IVCMinfinaRB» [In Russian].

3. Golovnina, O. V. (2007). Arahnojentomozy melkih domashnih zhivotnyh i metody bor'by s nimi [Meningomyiases of Small Domestic Animals and Methods of Fighting Them]. Veterinarnaja patologija, 2 (21), pp. 195-197 [In Russian].

4. Ljutikova, I. A. (2008). Ktenocefalidoz sobak i koshek megapolisa Moskvy: rasprostranenie, patogenez, terapija [Ctenocephalidosis of Dogs and Cats in Moscow Megapolis]. Candidate's thesis. Moskva [In Russian].

5. Mashkej, Y. A. (1998). Arahnoentomozy sobak ta kishok Ukrai'ny [Meningomyiases of Dogs and Cats in Ukraine]. Problemy veterynarnogo obslugovuvannja dribnyh domashnih tvaryn, pp. 14-16 [In Ukrainian].

6. Medvedev, S. G. (2002). Osobennosti rasprostranenija i parazito-hozjainnyh svjazej bloh (Siphonaptera) [The Peculiarities of Spreading and Host-Parasite Relationships of Fleas (Siphonaptera)]. Jentomologicheskoe obozrenie, 81 (3), pp. 737-751
Шкред М. А., Пономаренко О. В. Ефективність препарату "Рro meris duo" при ктеноцефальозі собак та котів. Ветеринарна медицина. 2009. Вип. 92. С. 404-407.

8. Chesney C. J. Species of flea found on cats and dogs in south west England: further evidence of their polyxenous state and implications for flea control. Veterinary Record. 1995. № 136 (14). P. 356-358.

9. De Avelar D. M., $\quad$ Bussolotti A. S., Ramos M. C. A., Linardi P. M. Endosymbionts of Ctenocephalides felis felis (Siphonaptera: Pulicidae) obtained from dogs captured in Belo Horizonte, Minas Gerais, Brazil. Journal of Invertebrate Pathology. 2007. № 94 (2). P. 149-152.

10. Linardi P. M., Santos J. L. Ctenocephalides felis felis vs. Ctenocephalides canis (Siphonaptera: Pulicidae): some issues in correctly identify these species. Brazilian Journal of Veterinary Parasitology. 2012. № 21 (4). P. 345-354.

11. Sammar A. P. Traditional Dog Breeding of the Nanai. Vladivostok: Dalnauka Press, 2010. 255 p.

[In Russian].

7. Ponomarenko, A. M., Klimchuk, O. O., Shkred, M. A., Ponomarenko, O. V. (2009). Efektyvnist' preparatu "Pro meris duo" pry ktenocefal'ozi sobak ta kotiv [The Effectiveness of "Pro meri duo" Preparation at ctenocephalidosis of Dogs and Cats]. Veterynarna medycyna, 92, pp. 404-407 [In Ukrainian].

8. Chesney, C. J. (1995). Species of flea found on cats and dogs in south west England: further evidence of their polyxenous state and implications for flea control. Veterinary Record, 136 (14), pp. 356-358 [In English].

9. De Avelar, D. M., Bussolotti, A. S., Ramos, M. C. A., Linardi, P. M. (2007). Endosymbionts of Ctenocephalides felis felis (Siphonaptera: Pulicidae) obtained from dogs captured in Belo Horizonte, Minas Gerais, Brazil. Journal of Invertebrate Pathology, 94 (2), pp. 149-152 [In English].

10. Linardi, P. M., Santos, J. L. (2012). Ctenocephalides felis felis vs. Ctenocephalides canis (Siphonaptera: Pulicidae): some issues in correctly identify these species. Brazilian Journal of Veterinary Parasitology, 21 (4), pp. 345-354 [In English].

11. Sammar, A. P. (2010). Traditional Dog Breeding of the Nanai. Vladivostok: Dalnauka Press [In English]. 


\section{ВЕТЕРИНАРНА МЕДИЦИНА}

Горб К.О. Эпизоотологические особенности ктеноцефалеза собак в условиях города Полтавы

Цель статьи заключается в том, чтобы изучить эпизоотологические особенности ктеноцефалеза собак на территории города Полтавы, поскольку ктеночефалез является одним из самых распространенных заболеваний собак, которое вызывается блохами рода Ctenосерhalides.

Методика исследования. Методологической основой исследования были следуюшие научные методы: анализ и синтез (выявление показателей инвазивности собак блохами, определение возрастной динамики ктеноцефалеза собак), теоретический поиск и абстрактно-логический (анализ исследований заболеваний собак ктеночефалезом, вызванным блохами рода Ctenocephalides), графический (отображение результатов исследований графически).

Результаты исследования. Показаны результаты исследований по изучению распространения ктеночефалеза собак на территории города Полтавы, учитывая зависимость показателей экстенсивности инвазии от породы и возраста животных. Энтомологические исследования проводили методом вычесывания волосяного покрова животных и сбора блох с их типичных мест обитания на теле собак. Ктеноцефалез установлен у собак старше одного года. Однако максимально заражаются блохами собаки в возрасте от одного до шести лет (ЭИ - 50,0-62,8\%). Установлено, что наиболее восприимчивыми к возбудителям ктеноцефалеза оказались собаки охотничьих пород (ЭИ 53,5\%) и беспородные животные (ЭИ - 60,7\%). Наименее пораженными были собаки декоративных пород (ЭИ-18,6\%).

Элементы научной новизны. Доказано, что ктеноцефалез является распространенной инвазией собак на территории города Полтавы. Причем к инвазированию блохами оказались склонны животные обоих полов. Определены показатели инвазивности собак блохами; исследована возрастная динамика ктеночефалеза собак; изучена породная восприимчивость собак к возбудтелям ктеноце фалеза.

Практическая значимость. Изучение эпизоотической ситуации по ктеноцефалезу собак в условиях 2. Полтавы осуществлялось по результатам исследований животных, которые поступали в ветеринарный сервис «Vеtехрегt» из разных административных районов г. Полтавы в 2017-2018 г2. Всего обследовано 187 собак. Средняя экстенсивность инвазии составила 43,85\%. Зафиксировано, что наиболее восприимчивыми к кровососущуим насекомым среди собак декоративных пород является китайская чихуа-хуа (50,0\%), охотничьих пород - лабрадор-ретривер и кокер-спаниель (60,063,6\%), служебных пород - немецкая овчарка и американский стаффордиирский терьер (62,9$71,4 \%)$

Ключевые слова: ктеноцефалез, собаки, распространение, возрастная динамика, породная восприимчивость.

Горб Ксения Олеговна - соискатель высшего образования степени доктора философии кафедры паразитологии и ветеринарно-санитарной экспертизы, Полтавская государственная аграрная академия, ул. Сковороды, 1/3, г. Полтава, 36003, Украина, e-mail: ksenia_92@ukr.net.

\section{Horb K.O. Epizootic peculiarities of dog ctenocephalosis in the conditions of the town of Poltava}

The aim of the article is to study the epizootic peculiarities of dog ctenocephalosis on the territory of the town of Poltava, as ctenocephalosis is one of the most widely spread dog diseases, caused by fleas of genus Ctenocephalides.

Methods of the research. The following scientific methods were the methodological basis of the research: analysis and synthesis (establishing infestation indices of dogs by fleas; determining age dynamics of dog ctenocephalosis); theoretical search and abstract-logical (the analysis of the research as to the disease incidence of dog ctenocephalosis, caused by fleas of genus Ctenocephalides); graphical (the reflection of the research results by graphics).

The research results. The research results as to studying the spreading of dog ctenocephalosis on the territory of Poltava were given in the article. The indices of the invasion prevalence depending on animals' breed and age were taken into account. Entomological examination was conducted by combing out animals' hair-coat covering and collecting fleas from their typical places of inhabiting on the dogs' body. Ctenocephalosis was revealed by us in dogs older than one year. However, dogs are maximally infested by fleas at the age from one to six years (EI-50,0-62,8\%). It was found out, that dogs of hunting breeds (EI-53,5\%) 


\section{ВЕТЕРИНАРНА МЕДИЦИНА}

and non-pedigree animals (EI- 60,7\%) are susceptible to ctenocephalosis causal agents most of all. The dogs of ornamental breeds were the least infested (EI-18,6\%).

The elements of scientific novelty. It has been established, that ctenocephalosis is a widely spread invasion on the territory of Poltava. Moreover, the animals of both sexes turned out to be susceptible to flea infestation. Infestation indices of dogs with fleas were determined; age dynamics of dog ctenocephalosis was defined; breed susceptibility of dogs to ctenocephalosis causal agents was investigated.

Practical importance. The studying of epizootic situation as to dog ctenocephalosis in Poltava was conducted according to the research results of animals from different administrative districts of Poltava; the dogs were examined in the veterinary service "Vetexpert" during 2017-2018. In all, 187 dogs were examined. The average prevalence of infestation was 43,85\%. It was established, that the most susceptible to blood-sucking insects among the dogs of ornamental breeds are the Chinese chihuahua (50\%), hunting breeds -Labrador-retriever and cocker spaniel (60,0-63,6\%), utility breeds - German sheep-dog and American Staffordshire terrier (62,9-71,4\%).

Keywords: ctenocephalosis, dogs, spreading, age dynamics, breed susceptibility.

Horb Kseniia Olehivna - Ph.D. degree applicant of higher education of the Department of parasitology and veterinary-sanitary expert examination, Poltava State Agrarian Academy, 1/3, Skovorody str., Poltava, 36003, Ukraine, e-mail: ksenia_92@ukr.net.

Стаття надійшла до редакції 12.02.2019 р.

Бібліографічний опис для цитування :

Горб К. О. Епізоотологічні особливості ктеноцефальозу собак в умовах міста Полтави. Вісник ПДАА. 2019. № 1. С. 216-221.

DOI 10.31210/visnyk2019.01.25

(с) Горб Ксенія Олегівна, 2019 